\title{
Identification of a group of shigella-like isolates as Shigella boydii 20
}

\author{
Francine Grimont, ${ }^{1}$ Monique Lejay-Collin, ${ }^{1}$ Kaisar A. Talukder, ${ }^{2}$ \\ Isabelle Carle, ${ }^{1}$ Sylvie Issenhuth, ${ }^{1}$ Karine Le Roux ${ }^{1}$ \\ and Patrick A. D. Grimont ${ }^{1}$
}

Correspondence

Francine Grimont pfgrimont@free.fr

Received 4 July 2006

Accepted 15 January 2007

\author{
${ }^{1}$ French National Reference Centre for Escherichia coli and Shigella, Unité de Biodiversité des \\ Bactéries Pathogènes Emergentes, Institut Pasteur, Paris, France \\ ${ }^{2}$ International Centre for Diarrhoeal Diseases Research, Dhaka-100, Bangladesh
}

\section{INTRODUCTION}

Shigellae cause diseases ranging from diarrhoea to bacillary dysentery, an invasive infection of the human colon affecting humans in developing countries, and are associated with poor hygiene conditions. In industrialized or developed countries, common-source outbreaks occur sporadically and several outbreaks have been reported (Butler, 2000; Legros, 2004). The diarrhoeal disease is highly contagious due to its low infectious dose.

The genus Shigella comprises four subgroups that historically have been treated as species (Enterobacteriaceae Subcommittee of the Nomenclature Committee of the International Association of Microbiological Societies, 1958): subgroup A is referred to as Shigella dysenteriae, subgroup B as Shigella flexneri, subgroup C as Shigella boydii and subgroup D as Shigella sonnei. In fact, these four so-called species constitute with Escherichia coli a single genomic species (Brenner et al., 1972, 1973), with the exception of S. boydii 13, which is synonymous with Escherichia alberti (Brenner et al., 1982; Huys et al., 2003). Phylogenetically, the shigellae (except S. boydii 13) are distributed in seven clusters within the E. coli branch (Lan \& Reeves, 2002).

Shigella species cannot be easily identified by biochemical properties alone, and definitive identification requires serotyping (Ewing et al., 1958; Ewing \& Lindberg, 1984). Based on somatic antigen (O-antigen) properties, $\mathrm{S}$. dysenteriae is subdivided into 15 serogroups (Bopp et al., 2003) and 2 provisional serogroups (Ansaruzzaman et al., 1995; Coimbra et al., 2001b; Melito et al., 2005). S. flexneri is subdivided into six serogroups and $S$. sonnei has a single serogroup which is divided into biotypes a, $\mathrm{d}, \mathrm{e}, \mathrm{f}$ and $\mathrm{g}$ (Janda \& Abbott, 1988). Previously S. boydii consisted of 19 serogroups. In 1986, Ewing (1986) acknowledged 17 serogroups, including two provisional serogroups represented by reference strain $2710-54$ as S. boydii 16 and 361553 as S. boydii 17. Gross et al. (1980) reported a new provisional serogroup with strain E10163, isolated in Bangladesh. Brenner and the International Committee on Systematic Bacteriology Subcommittee on the Taxonomy of Enterobacteriaceae (Brenner, 1984) recommended that the strain be added to the scheme as S. boydii 18. More biochemical and serological studies were presented by 
Wathen-Grady et al. (1985), and subsequently the designation S. boydii 19 for the provisional serogroup E16553 was published by Gross et al. (1982), Bopp et al. (2003) and Ansaruzzaman et al. (2005).

During a period of 5 years (January 2000-December 2004), the French National Reference Center for Escherichia coli and Shigella (FNRCECS) received a total of 4198 isolates of Shigella isolated from diverse laboratories in France in different geographical locations (France and abroad) from patients suffering from diarrhoea. S. sonnei, the most predominant species, accounted for $50 \%$, followed by $S$. flexneri (35\%), S. boydii (5\%) and S. dysenteriae (4\%). One hundred and eighty isolates $(6 \%)$ were serologically not typable.

A new provisional serogroup represented by strain $99-4528$ isolated in Canada was reported in an epidemiological investigation. This strain was designated by the World Health Organization (WHO) Collaborating Centre for Shigella the reference strain for S. boydii 20 by Kalluri et al. (2004) but no microbiological or molecular features were reported. Very recently, Woodward et al. (2005) reported a study on the same new serogroup with laboratory and epidemiological information on a collection of clinical isolates in Canada and the USA.

In the work presented here, we have studied the 180 nontypable Shigella isolates above. We describe their characteristics with respect to biochemical test results, presence of pathogenicity genes, ribotype pattern (Grimont \& Grimont, 1986; Coimbra et al., 2001c; Machado et al., 1998), molecular serotyping with RFLP of the amplified O-antigen gene cluster ( $r f b$ genes) (Coimbra et al., 1999, 2000) and RFLP of the amplified cryptic flagellin gene ( $f l i C)$ (Coimbra et al., 2001a; Machado et al., 2000), and agglutination by a serum raised against representative strain 00-977. The reference strain of $S$. boydii 20 (CDC 99-4528), received recently, was agglutinated by anti-00-977 serum, and was studied using the same methods, and compared with the other strains.

\section{METHODS}

Bacterial isolates. A total of 180 isolates of Shigella from diverse laboratories from patients in different geographical locations in France (145) and abroad (35) that did not agglutinate with available Shigella antisera were studied. Strain CDC 99-4528, the reference strain for S. boydii 20, was received from Dr N. Strockbine, CDC, Atlanta, GA, USA.

Biochemical tests. Cultures were grown at $37{ }^{\circ} \mathrm{C}$ on Drigalski agar for identification. All isolates (180) were subjected to the following biochemical tests: motility, glucose (acid and gas), $\mathrm{H}_{2} \mathrm{~S}$, indole production, lysin decarboxylase, ornithine decarboxylase, dulcitol, glycerol, lactose, D-mannitol, mucate, rhamnose and D-xylose. Twenty-seven randomly chosen clinical isolates were subjected to the 36 biochemical tests listed in Table 1 by conventional methods as described by Ewing (1986).

Seroagglutination. Slide agglutination was performed with appropriate antisera raised against all recognized Shigella antigens
Table 1. Biochemical reactions of serogroup 00-977 (S. boydii 20)

+ , Positive (1-2 days); -, negative.

\begin{tabular}{|c|c|}
\hline Biochemical reaction & Reaction \\
\hline Motility & - \\
\hline Glucose (acid) & + \\
\hline Glucose (gas) & - \\
\hline $\mathrm{H}_{2} \mathrm{~S}$ & - \\
\hline Urease & - \\
\hline Indole production & - \\
\hline Lysine decarboxylase & - \\
\hline Arginine dihydrolase & - \\
\hline Ornithine decarboxylase & - \\
\hline Tryptophan deaminase & - \\
\hline$\beta$-Galactosidase (ONPG) & - \\
\hline Christensen's citrate & - \\
\hline Simmons' citrate & - \\
\hline Gelatin & - \\
\hline Voges-Proskauer $\left(37^{\circ} \mathrm{C}\right)$ & - \\
\hline $\mathrm{NO}_{2}$ from $\mathrm{NO}_{3}$ & + \\
\hline Oxidase & - \\
\hline Adonitol & - \\
\hline L-Arabinose & + \\
\hline Dulcitol & - \\
\hline Glycerol & - \\
\hline myo-Inositol & - \\
\hline Lactose & - \\
\hline Malonate & - \\
\hline Maltose & - \\
\hline D-Mannitol & + \\
\hline D-Mannose & + \\
\hline Melibiose & - \\
\hline Mucate & - \\
\hline Raffinose & - \\
\hline Rhamnose & - \\
\hline Salicin & - \\
\hline Sorbitol & - \\
\hline Sucrose & - \\
\hline Trehalose & + \\
\hline D-Xylose & - \\
\hline
\end{tabular}

(Eurobio). In addition, two antisera against strains 00-977 and CDC 99-4528 were raised by injecting New Zealand rabbits with heatkilled bacteria (Ewing \& Lindberg, 1984). Cross-absorptions were performed with both antisera and both reference strains.

Antimicrobial susceptibility testing. Susceptibility to antimicrobial agents was determined on Mueller-Hinton (MH) agar by the disc diffusion method following the guidelines of the French National Antibiogram Committee (communiqué 2003, www.sfm.asso.fr/nouv/ general.php?pa=2). The following antimicrobial discs (Bio-Rad) were used: amoxicillin, ticarcillin, ticarcillin-clavulanic acid, piperacillin, piperacillin-tazobactam, cephalothin, cefamandole, cefoperazone, cefoxitin, ceftriaxone, ceftazidime, moxalactam, aztreonam, imipenem, streptomycin, spectinomycin, kanamycin, tobramycin, netilmicin, gentamicin, amikacin, nalidixic acid, ofloxacin, ciprofloxacin, sulfonamides, trimethoprim, chloramphenicol and tetracyline. 
Detection of pathogenicity genes by PCR. DNA was prepared (Grimont \& Grimont, 1995) from 27 isolates and examined by PCR for the presence of the invasion-associated locus (ial) and the invasion plasmid antigen $\mathrm{H}$ (ipaH) of Shigella as described by Frankel et al. (1990) and Sethabutr et al. (1993). PCR assays to demonstrate the presence of Shiga toxin (stx), Shigella enterotoxin 1 (ShET-1; gene set1), Shigella enterotoxin 2 (ShET-2; gene sen) and IS630 were performed as described by Lin et al. (1993), Vargas et al. (1999) and Houng et al. (1997) in a DNA thermal cycler (GenAmp 9700; Applied Biosystems). Amplification products were subjected to gel electrophoresis in $2 \%$ agarose and detected by staining with ethidium bromide.

\section{Molecular serotyping}

$r f b-R F L P$. Analysis of the $r f b$ gene cluster by amplification and restriction of the amplified product with endonuclease MboII was carried out as described by Coimbra et al. (1999). Patterns were analysed and compared against the established Shigella and E. coli database (Coimbra et al., 1999, 2000) using programs of the Taxotron package (Grimont, 2000). Molecular masses of the fragments were estimated by the Spline algorithm (Grimont, 2000). In pattern comparisons, the maximum fragment size variation accepted ranged from $7 \%$ for $500 \mathrm{bp}$ to $3.5 \%$ for $4000 \mathrm{bp}$.

fliC-RFLP. Analysis of the cryptic flagellin gene $(f l i C)$ by amplification and restriction of the amplified product with endonuclease HhaI was done following the method of Machado et al. (1998). Patterns were analysed and compared against the established Shigella and E. coli database (Machado et al., 2000; Coimbra et al., 2001a) using the Taxotron package. Molecular masses of the fragments were estimated by the Schaffer and Sederoff algorithm (Grimont, 2000). In pattern comparisons, the percentage of tolerated fragment size variation was set to $3.5 \%$.

Ribotyping. Fifty isolates were subjected to automated ribotyping using the RiboPrinter Microbial Characterization System (Qualicon) according to the manufacturer's instructions. Restriction endonuclease digestion by $M l u \mathrm{I}$, gel separation, transfer and hybridization with a chemiluminescent-labelled DNA probe containing the rRNA operon from $E$. coli were done automatically in $8 \mathrm{~h}$. Ribotype numbering and identification were generated by this system. The gel images were also analysed with programs of the Taxotron package, and ribopatterns were compared to the Shigella and E. coli MluI ribotype databases. A maximum fragment size variation of $5 \%$ was accepted.

\section{RESULTS}

\section{Biochemical tests}

All of the 180 isolates were non-motile rods, fermented Dmannitol and failed to produce indole. The biochemical reactions of strain 00-977 are presented in Table 1.

\section{Serological tests}

Except for five rough isolates (2.8\%), all isolates (180) and the reference strain CDC 99-4528 (S. boydii 20) agglutinated solely with the antiserum raised against strain 00977. Subsequently, an anti-CDC 99-4528 serum was prepared. Strains 00-977 and CDC 99-4528 agglutinated with the two antisera raised against these two strains (both at 1/500). After cross-absorptions of the two antisera with the two strains, no agglutinations were observed with the strains: antiserum against strain CDC 99-4528 absorbed with strain 00-977 did not agglutinate strain CDC 99-4528, and conversely antiserum against strain 00-977 absorbed with strain CDC 99-4528 did not agglutinate strain 00-977.

\section{Antimicrobial susceptibility}

All 27 isolates tested were susceptible to piperacillin and piperacillin-tazobactam, cephalothin, cefamandole, cefoperazone, cefoxitin, ceftriaxone, ceftazidime, moxalactam, aztreonam, imipenem, kanamycin, tobramycin, netilmicin, gentamicin, amikacin, nalidixic acid, ofloxacin, ciprofloxacin and chloramphenicol. They were all resistant to amoxicillin, ticarcillin, ticarcillin-clavulanic acid, streptomycin, spectinomycin and trimethoprim; $17(63.0 \%)$ isolates were also resistant to sulfonamide and tetracycline, $6(22.2 \%)$ isolates to sulfonamide and $2(7.4 \%)$ to tetracycline.

\section{Detection of pathogenicity genes by PCR}

All isolates tested and the reference strain CDC 99-4528 were positive for $i a l$ and $i p a H$ invasion-associated genes, sen and IS630 sequences. One strain isolated in 2000 was rough and carried ipaH but not ial. The PCR tests for $s t x$ and set 1 genes were negative for all strains tested.
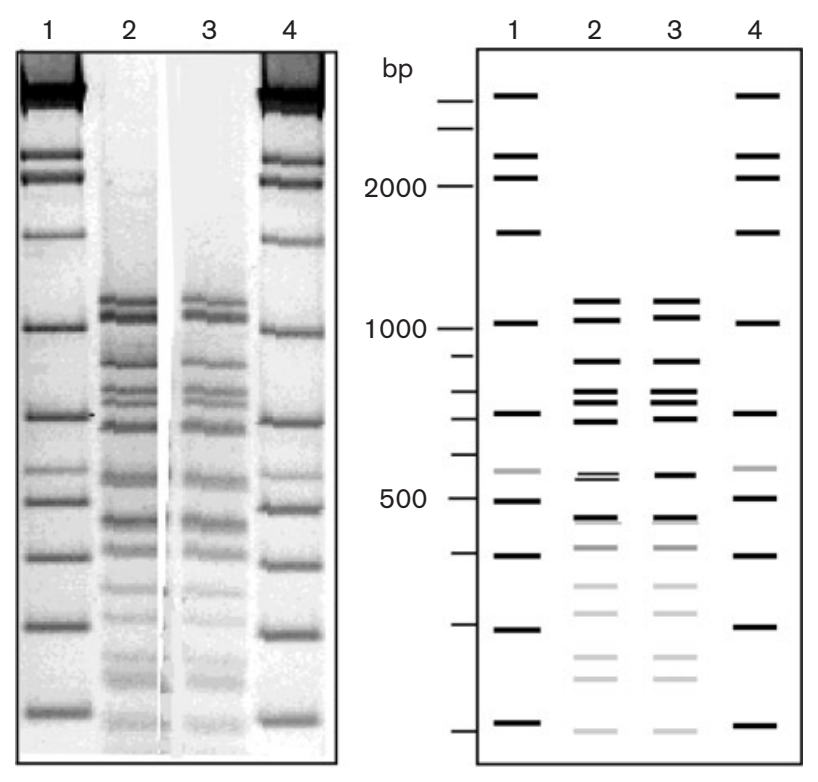

Fig. 1. Mboll-RFLP patterns (and schematic representation) of the amplified $r f b$ gene cluster. Lanes: 1 and 4, molecular mass marker (mixture of lambda-Hindlll and AmpliSize Molecular Ruler); 2, 00-977; 3, CDC 99-4528; same RN1 type. 


\section{rfb-RFLP}

A single restriction pattern was shown by all 27 isolates and by the reference strain CDC 99-4528 (Fig. 1). This unique pattern was clearly different from any other pattern in our database for Shigella and E. coli O groups, including the unique $r f b$ pattern of $S$. flexneri serogroups $1-5$.

\section{flic-RFLP}

All the 27 isolates and the reference strain CDC 99-4528 gave a single restriction pattern (Fig. 2). This pattern was identical to pattern $\mathrm{P} 4$, which is associated with $S$. boydii serogroups 1, 2, 3, 4, 6, 8, 10, 11, 14 and 18; S. flexneri 6; and $S$. dysenteriae serogroups 4, 5, 6, 7, 9, 11 and 12 .

\section{Ribotyping}

Fifty isolates tested and the reference strain CDC 99-4528 showed the same ribotype, RQ1 (Fig. 3), which was unique. This ribotype was compared with those in the Shigella and E. coli MluI ribotype databases and was clearly different from any other profile (Fig. 4). The closest profile in the database was $\mathrm{C} 1 \mathrm{~b} / 3 / 8 / 10 \mathrm{~b} / 18$ of $S$. boydii (Coimbra et al., 2001c), with seven common bands and two different bands.

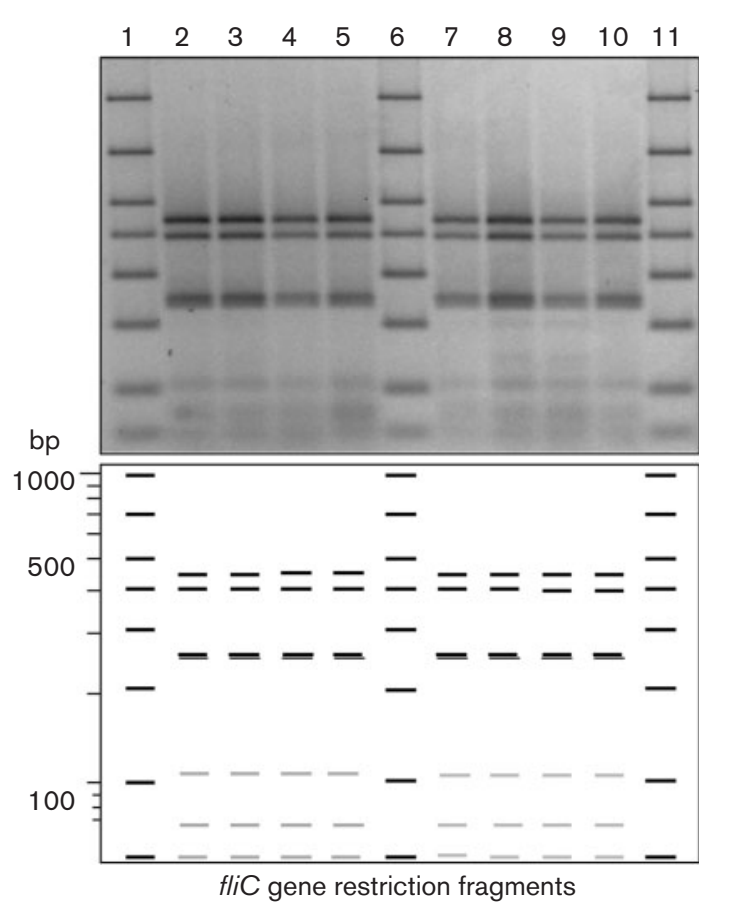

Fig. 2. Hhal-RFLP patterns (and schematic representation) of the Shigella amplified fliC gene. Lanes: 1, 6 and 11, molecular mass marker (AmpliSize Molecular Ruler); 2, 00-977; 3, 01-6104; 4, 01-6419; 5, 02-110; 7, 04-059; 8, 00-3176; 9, 02-4425; 10, CDC 99-4528; same P4 type.

\section{DISCUSSION}

The FNRCECS received 180 atypical strains of Shigella isolated from patients from January 2000 to December

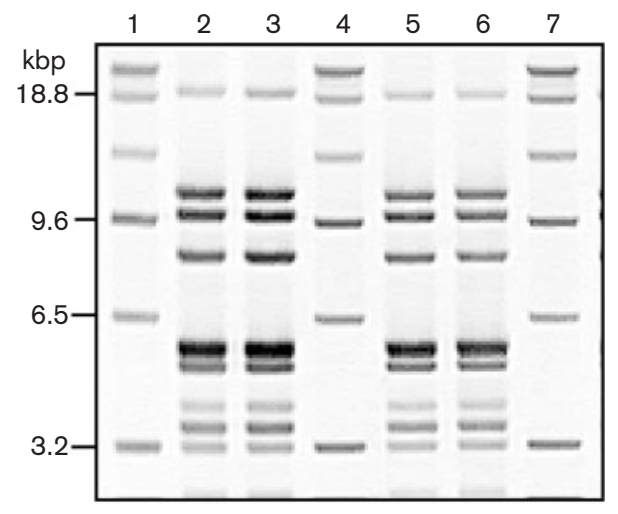

Fig. 3. Ribotypes of four Shigella boydii 20 strains. Lanes: 1,4 and 7, molecular mass marker; 2, 00-977; 3, 01-6104; 5, 04-059; 6, CDC 99-4528; same ribotype RQ1.

\begin{tabular}{|c|c|}
\hline & Size of DNA fragments \\
\hline $\mathrm{kbp}$ & $\begin{array}{llllll}22.0 & 9.6 & 6.5 & 3.2 & 1 \\
\end{array}$ \\
\hline $1 \mathrm{a}$ & || || | | | \\
\hline $\mathrm{C} 1 \mathrm{~b} / 3 / 8 / 10 \mathrm{~b} / 18$ & l| | | | | | \\
\hline $\mathrm{C} 2 / 4$ & $\begin{array}{lllllllll} & 1 & 1 & 1 & 11 & 1 & 1 & 1 & 1\end{array}$ \\
\hline Сз & I III II | | | | \\
\hline C5 & | I| I II | | | \\
\hline $\mathrm{C} 6$ & II III | II | | | | \\
\hline C7 & | I| I II | | | \\
\hline C9 & III | || | | | \\
\hline $\mathrm{C} 10 \mathrm{a}$ & $\begin{array}{lllllll}\mid 1 & I I & I & \mid & \mid\end{array}$ \\
\hline C11 & | I| I II I | I \\
\hline $\mathrm{C} 12$ & | IIII III | | I \\
\hline $\mathrm{C} 13$ & $\begin{array}{lllll}|| & \mid & \mid & \mid\end{array} \mid$ \\
\hline C14 & $\mid \begin{array}{lll}\mid & I & I I\end{array}$ \\
\hline C15 & | I|| | || | | \\
\hline C16 & $\left|\begin{array}{lll|}|| & ||\end{array}\right|$ \\
\hline C17 & II I II | | | | \\
\hline C19 & IIII I II I | | \\
\hline 00-977 & I II I II III I I \\
\hline
\end{tabular}

Fig. 4. Ribotypes of 20 serogroups of Shigella boydii. 
2004 representing a mean of $4.3 \%$ of the total Shigella strains. The incidence of antigenically atypical strains which did not agglutinate with any available serum of Shigella was high in 2000 and accounted for $12.8 \%$ of Shigella strains. Since 2001, the incidence has been stable and they account for 1.5-3.1\% of Shigella strains. For 91 patients, there was a history of recent travel to Africa (Algeria, Burkina Fasso, Egypt, Ivory Coast, Mali, Morocco, Mauritania, Togo, Tunisia), Asia (Bangladesh, India, Kazakhstan, Yemen), America (Brazil, French Guyana, Cuba, St Domingue, Peru) and also Bosnia.

These strains were characterized as Shigella spp. by the presence of the invasion-associated locus (ial) and the invasion plasmid antigen $\mathrm{H}(\mathrm{ipaH})$ gene. All fermented Dmannitol and might therefore be classified as either $S$. boydii or S. flexneri. Since S. boydii is characteristically Dmannitol-positive $(98 \%)$, arabinose-positive $(94 \%)$ and invariably raffinose-negative (Ewing, 1986), strains of this group have properties compatible with S. boydii.

Resistance of Shigella spp. to various antibiotics is extremely common and is increasing (Sack et al., 1997). In this study, all the 27 strains tested were resistant to six antimicrobial agents, and $63.0 \%$ were resistant to eight. Woodward et al. (2005) found resistance to five antimicrobial agents in $92 \%$ of cases. If we consider the same antimicrobial agents (A-S-Su-T-Tm) as Woodward et al. (2005), we found a lower rate $(63.0 \%)$ due to a higher susceptibility to sulfonamides and tetracycline. We did not find any resistance to chloramphenicol in our strains, in contrast to Woodward et al. (2005), who found resistance in four strains. No correlation was observed between resistance and geographical origin.

Two novel toxins, ShET-1 encoded by the chromosomal gene set 1 and ShET-2 encoded by sen, associated with invasiveness of many Shigella spp., have been described in S. flexneri (Fasano et al., 1995). It is now known that sen is located on the invasion plasmid and is present in most strains of Shigella $(83 \%)$ and in $75 \%$ of EIEC (enteroinvasive E. coli) (Nataro et al., 1995). ShET-2 has been reported in different species of Shigella causing travellers' diarrhoea by Vargas et al. (1999), but the prevalence of both enterotoxins in $S$. boydii serogroups had not been hitherto reported. We have studied the occurrence of these two genes in 27 isolates of the new serogroup of Shigella and in a collection of 424 diverse Shigella strains which comprised: 214 S. flexneri, 164 S. sonnei, S. dysenteriae and 38 S. boydii (unpublished data). We found that sen is present in all S. boydii and S. dysenteriae strains, in $61 \%$ of $S$. sonnei strains and in $68 \%$ of $S$. flexneri strains. These results agree with those of Vargas et al. (1999), who found sen in all $S$. dysenteriae strains and in $58 \%$ of $S$. sonnei strains, with a lower rate for S. flexneri (14\%). In contrast, set1 was absent from S. boydii, S. dysenteriae, S. flexneri and S. sonnei, but Vargas et al. (1999) found set1 in $9 \%$ of S. flexneri strains. Talukder et al. (2002) reported that sen was present in all S. flexneri 4, but that set was absent.
All isolates of our studied group of Shigella had sen but not set.

Houng et al. (1997) showed that all species of Shigella and all serogroups of $S$. boydii contain the IS630 sequence. We confirmed the presence of the sequence in strains studied here. Therefore, the IS630 sequence, as well as ipaH and ial gene sequences (Frankel et al., 1990; Sethabutr et al., 1993), can be amplified by PCR to allow the detection of Shigella or EIEC.

Though Shigella species are non-motile and lack flagella, a cryptic fliC gene is almost always present. Coimbra et al. (2001a) studied cryptic fliC alleles in the genome of Shigella serogroups by restriction analysis and found 17 restriction patterns. All patterns of our strains belong to $f l i C$ pattern P4 of Coimbra et al. (2001a), which is shown by 10 serogroups of $S$. boydii and 7 serogroups of $S$. dysenteriae.

The combination of biochemical reactions and $r f b$-RFLP (RN1) and fliC-RFLP (P4) data suggest that these isolates constitute a distinct group of $S$. boydii. They were assigned to serogroup $S$. boydii 20 by their reactions with an antiserum that reacted with the reference strain for this serogroup. The reciprocal cross-agglutinations and crossabsorption with both antisera confirmed the antigenic identity of the two reference strains. The diverse geographical origins of the strains and the long time span over which they were isolated raise questions about the epidemiology of this serogroup and its potentially widespread public health significance.

\section{ACKNOWLEDGEMENTS}

We thank Nancy A. Strockbine (WHO Collaborating Center, Division of Bacterial and Mycotic Diseases, Centers for Disease Control and Prevention, Atlanta, GA, USA) for kindly providing the Shigella boydii 20 reference strain.

\section{REFERENCES}

Ansaruzzaman, M., Kibriya, A. K. M. G., Rahman, A., Neogi, P. K. B., Faruque, A. S. G., Rowe, B. \& Albert, M. J. (1995). Detection of provisional serovars of Shigella dysenteriae and designation as $S$. dysenteriae serogroups 14 and 15. J Clin Microbiol 33, 1423-1425.

Ansaruzzaman, M., Sultana, M., Talukder, K. A., Alam, K., Matsushita, S., Safa, A., Khajanchi, B. K., Dutta, D. K., Islam, Z. \& other authors (2005). Isolation and characterization of provisional serovar Shigella boydii E16553 from diarrhoeal patients in Bangladesh. J Med Microbiol 54, 477-480.

Bopp, C. A., Brenner, F. W., Fields, P. I., Wells, J. G. \& Strockbine, N. A. (2003). Escherichia, Shigella, and Salmonella. In Manual of Clinical Microbiology, 8th edn, pp. 654-671. Edited by P. R. Murray, E. J. Baron, J. H. Jorgensen, M. A. Pfaller \& R. H. Yolken. Washington, DC: American Society for Microbiology.

Brenner, D. J. (1984). Recommendations on recent proposals for the classification of shigellae. Int J Syst Bacteriol 34, 87-88.

Brenner, D. J., Fanning, G. R., Skerman, F. J. \& Falkow, S. (1972). Polynucleotide sequence divergence among strains of Escherichia coli and closely related organisms. J Bacteriol 109, 953-965. 
Brenner, D. J., Fanning, G. R., Miklos, G. V. \& Steigerwalt, A. G. (1973). Polynucleotide sequence relatedness among Shigella species. Int J Syst Bacteriol 23, 1-7.

Brenner, D. J., Steigerwalt, A. G., Wathen, G. H., Gross, R. J. \& Rowe, B. (1982). Confirmation of aerogenic strains of Shigella boydii 13 and further study of Shigella serogroups by DNA relatedness. J Clin Microbiol 16, 432-436.

Butler, T. (2000). Shigellosis. In Textbook of Medicine, 21st edn, pp. 1685-1687. Edited by L. Goldman \& J. C. Bennett. Philadelphia, PA: W. B. Saunders.

Coimbra, R. S., Grimont, F. \& Grimont, P. A. D. (1999). Identification of Shigella serotypes by restriction of amplified O-antigen gene cluster. Res Microbiol 150, 543-553.

Coimbra, R. S., Grimont, F., Burguière, P., Lenormand, P., Beutin, L. \& Grimont, P. A. D. (2000). Identification of Escherichia coli Oserogroups by restriction of amplified $\mathrm{O}$-antigen gene cluster. Res Microbiol 151, 639-654.

Coimbra, R. S., Lefevre, M., Grimont, F. \& Grimont, P. A. D. (2001a). Clonal relationships among Shigella serotypes suggested by cryptic flagellin gene polymorphism. J Clin Microbiol 39, 670-674.

Coimbra, R. S., Lenormand, P., Grimont, F., Bouvet, P., Matsushita, S. \& Grimont, P. A. D. (2001b). Molecular and phenotypic characterization of potentially new Shigella dysenteriae serotype. J Clin Microbiol 39, 618-621.

Coimbra, R. S., Nicastro, G., Grimont, P. A. D. \& Grimont, F. (2001c). Computer identification of Shigella species by rRNA gene restriction patterns. Res Microbiol 152, 47-55.

Enterobacteriaceae Subcommittee of the Nomenclature Committee of the International Association of Microbiological Societies (1958). Supplement to the third report on the Shigella group. Int Bull Bacteriol Nomencl Taxon 8, 93-95.

Ewing, W. H. (1986). The genus Shigella. In Edwards and Ewing's Identification of Enterobacteriaceae, 4th edn, pp. 135-172. New York: Elsevier.

Ewing, W. H. \& Lindberg, A. A. (1984). Serology of Shigella. Methods Microbiol 14, 113-142.

Ewing, W. H., Reavis, R. W. \& Davis, B. R. (1958). Provisional Shigella serotypes. Can J Microbiol 4, 89-107.

Fasano, A., Noriega, F., Manevel, D. R., Chanasongcram, S., Rossell, R., Guandalini, S. \& Levine, M. M. (1995). Shigella enterotoxin 1: an enterotoxin of Shigella flexneri 2 a active in rabbit small intestine in vivo and in vitro. J Clin Invest 95, 2853-2861.

Frankel, G., Riley, L., Giron, J. A., Valmassoi, J., Friedmann, A., Strockbine, N., Falkow, S. \& Schoolnik, G. K. (1990). Detection of Shigella in feces using DNA amplification. J Infect Dis 161, 1252-1256.

Grimont, P. A. D. (2000). Taxotron User's Guide. Paris: Institut Pasteur.

Grimont, F. \& Grimont, P. A. D. (1986). Ribosomal ribonucleic acid gene restriction patterns as potential taxonomic tools. Ann Inst Pasteur Microbiol 137B, 165-175.

Grimont, F. \& Grimont, P. A. D. (1995). Determination of rDNA gene restriction patterns. Methods $\mathrm{Mol}$ Biol 46, 181-200.

Gross, R. J., Thomas, L. V. \& Rowe, B. (1980). New provisional serovar (E10163) of Shigella boydii. J Clin Microbiol 12, 167-169.

Gross, R. J., Thomas, L. V., Day, N. P., Cheasty, T. \& Rowe, B. (1982). New provisional serovar of Shigella boydii. J Clin Microbiol 16, 1000-1002.

Houng, H.-S. H., Sethabutr, O. \& Echeverria, P. (1997). A simple polymerase chain reaction technique to detect and differentiate
Shigella and enteroinvasive Escherichia coli in human feces. Diagn Microbiol Infect Dis 28, 19-25.

Huys, G., Cnockaert, M., Janda, J. M. \& Swings, J. (2003). Escherichia albertii sp. nov., a diarrhoeagenic species isolated from stool specimens of Bangladeshi children. Int J Syst Evol Microbiol 53, 807-810.

Janda, J. M. \& Abbott, S. L. (1988). The genus Shigella. In The Enterobacteria, pp. 66-79. Philadelphia, PA: Lippincott-Raven.

Kalluri, P., Cummings, K., Abbott, S. L., Malcolm, G. B., Hutcheson, K., Beall, A., Joyce, K., Polyak, C., Woodward, D. \& other authors (2004). Epidemiological features of a newly described serotype of Shigella boydii. Epidemiol Infect 132, 579-583.

Lan, R. \& Reeves, P. R. (2002). Escherichia coli in disguise: molecular origins of Shigella. Microbes Infect 4, 1125-1132.

Legros, D. (2004). Shigellosis: report of a workshop. J Health Popul Nutr 22, 445-449.

Lin, Z., Kurazono, H., Yamasaki, S. \& Takeda, Y. (1993). Detection of various variant verotoxin genes in E. coli by PCR. Microbiol Immunol 37, 543-548.

Machado, J., Grimont, F. \& Grimont, P. A. D. (1998). Computer identification of Escherichia coli rRNA gene restriction patterns. Res Microbiol 149, 119-135.

Machado, J., Grimont, F. \& Grimont, P. A. D. (2000). Identification of Escherichia coli flagellar types by restriction of the amplified fliC gene. Res Microbiol 151, 535-546.

Melito, P. L., Woodward, D. L., Munro, J., Walsh, J., Foster, R., Tilley, P., Paccagnella, A., Isaac-Renton, J., Ismail, J. \& Ng, L. K. (2005). A novel Shigella dysenteriae serovar isolated in Canada. J Clin Microbiol 43, 740-744.

Nataro, J. P., Seriwatana, J., Fasano, A., Maneval, D. R., Guers, L. D., Noriega, F., Dubovsky, F., Levine, M. M. \& Morris, J. G., Jr (1995). Identification and cloning of a novel plasmid-encoded enterotoxin of enteroinvasive Escherichia coli and Shigella strains. Infect Immun 63, 4721-4728.

Sack, R. B., Rahman, M., Yunus, M. \& Khan, E. H. (1997). Antimicrobial resistance in organisms causing diarrheal disease. Clin Infect Dis 24, S102-S105.

Sethabutr, O., Venkatesan, M., Murphy, G. S., Eampokalap, B., Hoge, C. W. \& Echeverria, P. (1993). Detection of Shigellae and enteroinvasive Escherichia coli by amplification of the invasion plasmid antigen $\mathrm{H}$ DNA sequence in patients with dysentery. $J$ Infect Dis 167, 458-461.

Talukder, K. A., Islam, M. A., Dutta, D. K., Hassan, F., Safa, A., Nair, G. B. \& Sack, D. A. (2002). Phenotypic and genotypic characterization of serologically atypical strains of Shigella flexneri type 4 isolated in Dhaka, Bangladesh. J Clin Microbiol 40, 24902497.

Vargas, M., Gascon, J., Jimenez de Anta, M. T. \& Vila, J. (1999). Prevalence of Shigella enterotoxins 1 and 2 among Shigella strains isolated from patients with traveler's diarrhea. J Clin Microbiol 37, 3608-3611.

Wathen-Grady, H. G., Davis, B. R. \& Morris, G. K. (1985). Addition of three new serotypes of Shigella boydii to the Shigella scheme. J Clin Microbiol 21, 129-132.

Woodward, D. L., Clark, C. G., Caldeira, R. A., Ahmed, R., Soule, G., Bryden, L., Tabor, H., Melito, P., Foster, R. \& other authors (2005). Identification and characterization of Shigella boydii 20 serovar nov., a new and emerging Shigella serotype. J Med Microbiol 54, $741-748$. 